\title{
STATISTICAL ANALYSIS AND EVALUATION OF PM CONCENTRATIONS DURING THE DUST STORMS AT MAY 2020 FOR SELÇUKLU DISTRICT OF KONYA CITY, TURKEY
}

\author{
Fatma KUNT \\ Zeynep Cansu AYTURAN \\ Şükrü DURSUN
}

Received: 22.05.2021; revised: 30.07.2021; accepted: 05.08.2021

\begin{abstract}
Dust storms are widespread events that occur several times a year and spread over many countries of the world relating the wind direction and speed. Especially particulate matter (PM) is the main pollutant spread over by these storms. Because of the dust storms, PM concentrations increase rapidly in the areas found on the way of dust storm passes In this study, statistical evaluation was made accordingly the PM data measured with personal measurement device in Selçuklu District of Konya and the meteorological and the air pollution data provided from air quality monitoring station, which is affiliated by the Ministry of Environment and Urbanization, located nearby. Pearson correlation test has been applied to both data sets and a significant relationship has been detected between the measured and provided data. Moreover, multiple linear regression was applied to the data for $\mathrm{PM}_{2.5}$ and $\mathrm{PM}_{10}$ separately. Adjusted $\mathrm{R}^{2}$ of the analysis has been found as 0.573 and 0.559 respectively for $\mathrm{PM}_{2.5}$ and $\mathrm{PM}_{10}$ which explains almost half of the relationship between PM and meteorological variables. The highest positive effect on PM pollution was determined as air temperature. Finally, principal component analysis (PCA) was applied to both data and 4 different principal components were detected. Measured $\mathrm{PM}_{2.5}$ and $\mathrm{PM}_{10}$, air temperature, and relative humidity were clustered at the same component group.
\end{abstract}

Keywords: Particulate matter, dust storms, statistical analysis, correlation test, multiple linear regression, PCA

\section{Mayıs Ayındaki Kum Fırtınası Sırasında Konya Selçuklu İlçesinde Ölçülen PM Konsantrasyonlarının İstatistiksel Analizi ve Değerlendirilmesi}

Öz: Toz firtınaları, rüzgârın yönü ve hızı ile ilgili olarak dünyanın birçok ülkesine yayılan ve yılda birkaç kez meydana gelen yaygın olaylardır. Özellikle partikül madde (PM), bu firtınalarla yayılan ana kirletici maddedir. Toz firtınaları nedeniyle, toz firtınası geçişleri yolunda bulunan alanlarda PM konsantrasyonları hızla artmaktadır. Bu çalışmada, istatistiksel değerlendirme Konya'nın Selçuklu ilçesinde ölçülen PM verileri ile yakınlarda bulunan Çevre ve Şehircilik Bakanlığına bağlı hava kalitesi izleme istasyonundan sağlanan meteorolojik ve kirlilik verilerine göre yapılmıştır. Her iki veri setine de Pearson korelasyon testi uygulanmış veriler arasında önemli bir ilişki tespit edilmiştir. Ayrıca, $\mathrm{PM}_{2.5}$ ve $\mathrm{PM}_{10}$ verilerine ayrı ayrı çoklu doğrusal regresyon uygulanmıştır. Regresyon analizinin düzeltilmiş $\mathrm{R}^{21}$ si $\mathrm{PM}_{2.5}$ ve $\mathrm{PM}_{10}$ için sırasıyla 0.573 ve 0.559 olarak bulunmuştur ve bu da PM ile meteorolojik değişkenler arasındaki ilişkinin neredeyse yarısını açıklamaktadır. Hava sıcaklığının, PM kirliliği üzerinde en yüksek pozitif etkiye sahip olduğu bulunmuştur. Son olarak, temel bileşen analizi (PCA) hem ölçülen hem de sağlanan verilere uygulanmış ve 4 farklı ana bileşen tespit edilmiştir. Ölçülen $\mathrm{PM}_{2.5}$ ve $\mathrm{PM}_{10}$, hava sıcaklığı ve bağıl nem aynı bileşen grubunda kümelenmiştir.

\footnotetext{
* Environmental Engineering Department, Engineering Faculty, Necmettin Erbakan University, 42090 Meram, Konya, Turkey

** Environmental Engineering Department, Engineering and Natural Science Faculty, Konya Technical University, 42250 Selçuklu, Konya, Turkey

Corresponding Author: Fatma Kunt (drfatmakunt@gmail.com)
} 
Anahtar Kelimeler: Partikül madde, toz firtınaları, istatistiksel analiz, korelasyon testi, Çoklu doğrusal regresyon, PCA

\section{INTRODUCTION}

Air pollution and its effects have become global issues since middle of 19s. Air pollution is transported to long distances with air movements and has global effects. The greenhouse effect major cause of global warming and depletion of ozone layer with effect of many primary and secondary pollutants are major effects of air pollutants. (Zannetti 1990). Main primary air pollutants which are contaminants causing some adverse effects on environment are particulate matter (PM), sulphur compounds (e.g., $\mathrm{SO}_{2}, \mathrm{H}_{2} \mathrm{~S}$ ), nitrogen compounds (e.g., $\mathrm{NO}, \mathrm{NH}_{3}$ ), carbon compounds (e.g., $\mathrm{HCs}, \mathrm{CO}, \mathrm{CO}_{2}$ ) and halogen compounds (e.g., fluorides, bromides, chlorides).

Sources of air pollution are separated as natural and anthropogenic. Anthropogenic air pollution is the waste remaining from the production, transportation, and energy generation ways of humans (Vesilind et al., 2010). Anthropogenic sources of air pollution are classified as the industrial sources, utilities, and personal sources. The main source of industrial air pollution originates from raw materials in manufacturing processes. For example, during mining activity dust and $\mathrm{SO}_{2}$ emissions, during briquetting \& coking of coal dust, gases and impurities of coal, during metal smelting $\mathrm{SO}_{2}$ and various volatile metals such as $\mathrm{Hg}, \mathrm{As}, \mathrm{Pb}, \mathrm{Cd}$, and from chemical industry $\mathrm{HCl}, \mathrm{HF}, \mathrm{H}_{2} \mathrm{~S}, \mathrm{NOx}, \mathrm{NH}_{3}, \mathrm{HCs}$, VOC are emitted. Utilities are the important source of anthropogenic air pollution because most of them produce electricity by converting energy. This procedure emits huge amount of carbon dioxide, nitrous and sulphur oxides to the atmosphere. Moreover, personal sources such as mobile vehicles, furnaces and stoves in homes, barbeque grills, and burning of leaves in open area contribute to anthropogenic air pollution (Boubel et.al 1994). The amount of gaseous and particulate matter in the air which harms the living organisms increases because majorly of the combustion of fossil fuels. Impurities in the fuel, poor air-to-fuel ratio, too high, and low combustion temperatures lead to the pollutants (Boubel et al., 1994

Besides, air pollution is produced by natural sources such as volcanic eruptions, oceans, forest fires, dust storms, etc. Particulate matter (PM) which is also known as particulate pollution naturally occurs in the dust from the earth's surface, sea salt, and biological material (Morand and Maesano, 2004). Volcanic eruptions produce huge amount of particulate matter and other pollutant gases like $\mathrm{SO}_{2}, \mathrm{H}_{2} \mathrm{~S}$, and methane. These gases and particulate matter stay in the air very long time. Forest fires are another main source of natural air pollution (Boubel et.al 1994).

PM is composed of very small particles and droplets of liquid. Many constitutions such as acids of sulfide and nitrate, organic compounds, metals, and dust particles produce particulate pollution. Moreover, particle size is an important factor affecting the health of all living creatures. Especially particles equal to or smaller than 10 microns are very important for investigators and they must be removed since these particles can pass through the nose and throat and affect the lungs and heart. This can lead to very serious health problems (EPA, 2020). Particulate matters or pollutants are classified into two categories according to the Environmental Protection Agency of the United States (EPA). These are named inhalable coarse particles and fine particles. The diameter of inhalable course particles $\left(\mathrm{PM}_{10}\right)$ is bigger than 2.5 microns and smaller than 10 microns. Fine particles $\left(\mathrm{PM}_{2.5}\right)$ have a diameter smaller than 2.5 microns. These particles are found in the atmosphere as a form of smoke and haze that are emitted directly from forest fires and power plants (EPA, 2020).

Turkey is one of the most influenced countries from dust storms coming from middle east countries because of the location. With the help of strict regulations and precautions, PM pollution levels have been lowered last years in most of the country. Dust storms are known as natural processes resulting in high concentrations of PM and they mainly originate from desert areas (Jaafari et al., 2018; Wang et al., 2005). PM levels of Turkey are also affected by these events negatively. Generally, these storms are produced by strong turbulent winds and convective haboobs and fronts are effective forces (Jaafari et al., 2018; Miller et al., 2008). Dust coming from 
desert areas sometimes may reach up to $6,000 \mu \mathrm{g} / \mathrm{m}^{3}$ and create serious effects on daily life such as reducing visibility and respiratory problems on humans (Jaafari et al., 2018; Song et al., 2007). With many epidemiological studies, a relationship has been found between the level of air pollution caused by PM and death cases due to respiratory diseases, lung, cardio and respiratory problems (Karakaş, 2015). Particulate matter exposure may create serious health effects concerning the results of several studies. In these studies, short-term exposure to PM has been found correlated with different health problems (Goudarzi et al., 2013; Linares et al., 2010; Malig and Ostro, 2009; Brunekreef and Forsberg, 2005; Graff et al., 2009; Host et al., 2008; Qiu et al., 2012).

In this study, $\mathrm{PM}_{10}$ pollution measured during a dust storm event in Konya city was evaluated by comparison with previous years' data. Moreover, statistical analysis was conducted for understanding the relation of meteorological parameters and other pollutants concentrations along with $\mathrm{PM}_{2.5}$ and $\mathrm{PM}_{10}$ concentrations.

\section{MATERIAL AND METHOD}

\subsection{Data}

Data including $\mathrm{PM}_{10}\left(\mu \mathrm{g} / \mathrm{m}^{3}\right)$, wind speed $(\mathrm{m} / \mathrm{s})$, air temperature $\left({ }^{\circ} \mathrm{C}\right)$, relative humidity $(\%)$, atmospheric pressure (mbar), wind direction (degree), $\mathrm{SO}_{2}\left(\mu \mathrm{g} / \mathrm{m}^{3}\right)$, and $\mathrm{CO}\left(\mu \mathrm{g} / \mathrm{m}^{3}\right)$ was provided from Ministry of Environment and Urbanization Air Quality Monitoring Station (AQMS). Also, the data including $\mathrm{PM}_{2.5}\left(\mu \mathrm{g} / \mathrm{m}^{3}\right)$ and $\mathrm{PM}_{10}\left(\mu \mathrm{g} / \mathrm{m}^{3}\right)$ was measured with Particle Counter Dust Measuring Device PCE-PCO 1. The Dust Meter PCE-PCO 1 is a universal measuring instrument developed for the measurement of the density of particles in air. The Dust Meter can measure particles of 6 different sizes. In addition, the Dust Meter can also measure temperature and air thanks to its sensor, thus making the Dust Meter a versatile device. The built-in camera allows us to connect with video and photographic measurement data. The Dust Measuring Device is a device developed to determine the pollution level precisely. All data were measured and provided hourly for 10 days' period between $16^{\text {th }}$ and $26^{\text {th }}$ May 2020. This period was determined according to the dust storm satellite images of NASA. After $26^{\text {th }}$ May 2020, dust storm above Konya region was moved to the north-west direction and the measurements were stopped.

\subsection{Study Area}

Konya city in the Central Anatolia Region of Turkey with the biggest surface area. It is also located on the passageway of the dust storm according to the satellite map images from NASA (NASA, 2020). In Figure 1, the $\mathrm{PM}_{2.5}$ pollution map of Turkey and neighboring countries was shown for 18 May 2020. Figure 1 shows that the $\mathrm{PM}_{2.5}$ values during that day were seen slightly high almost $100 \mu \mathrm{g} / \mathrm{m}^{3}$ around the middle part of Turkey. These high PM concentrations are mainly originating from the dust storm events. 


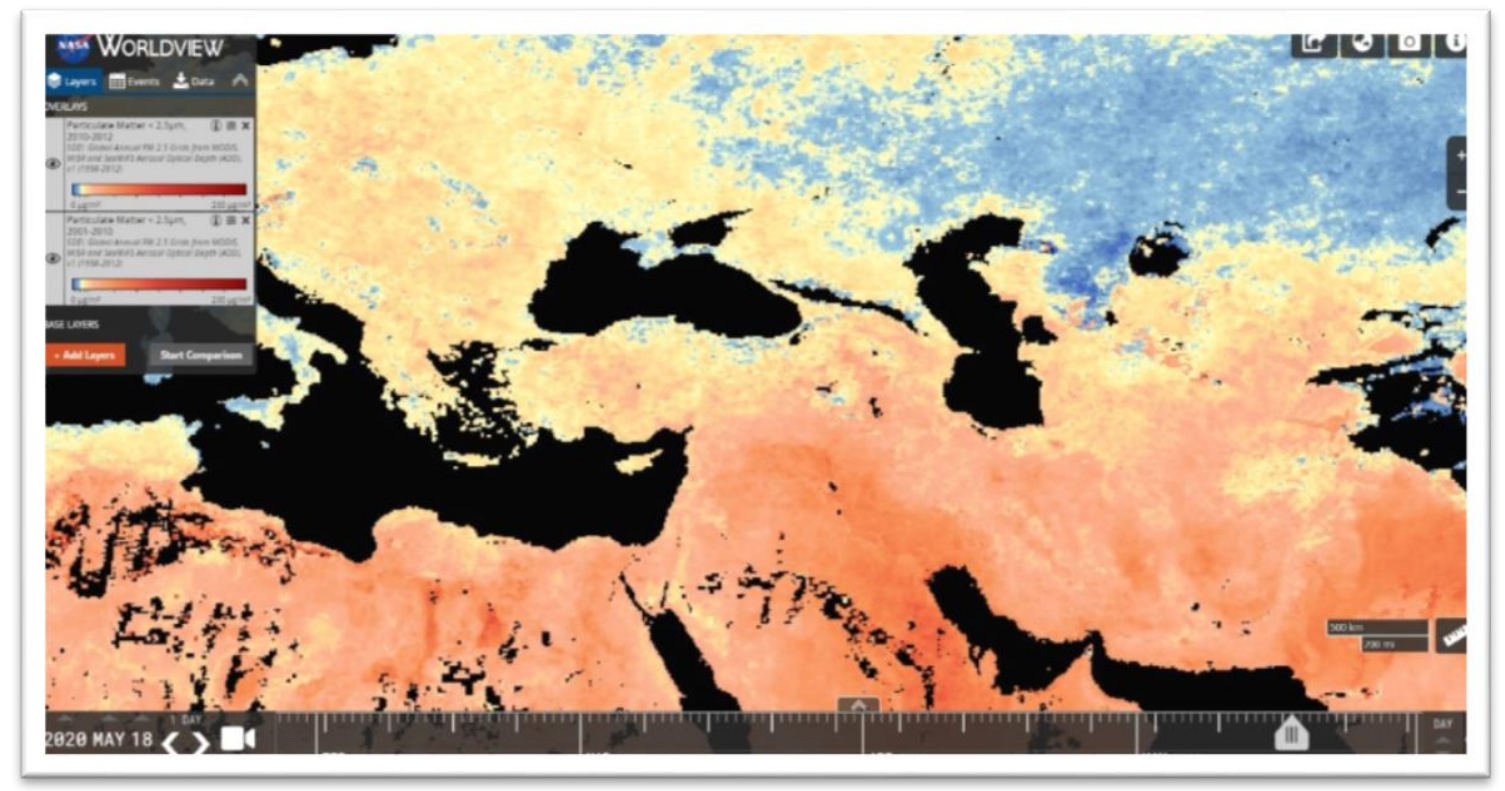

\section{Figure 1:}

PM2.5 pollution map of Turkey and the neighbor countries for 18 May 2020 (NASA, 2020)

Day and night dust score and aerosol optic depth value comparison of the same area were given in Figure 2 for 18 May 2020. Day and night dust scores represent the dust intensity on the area with a value between 400-500 (AIRS Level 1B). On 18 May 2020, some parts of Turkey had a high dust intensity with a score of around 500 (AIRS Level 1B). Also, the aerosol optic depth of the area indicating the measure of the extinction of the solar beam by dust and haze was seen close to the highest amount 5 in some parts of Turkey. That is dust particles in the atmosphere were blocked the sunlight by absorbing or scattering light.

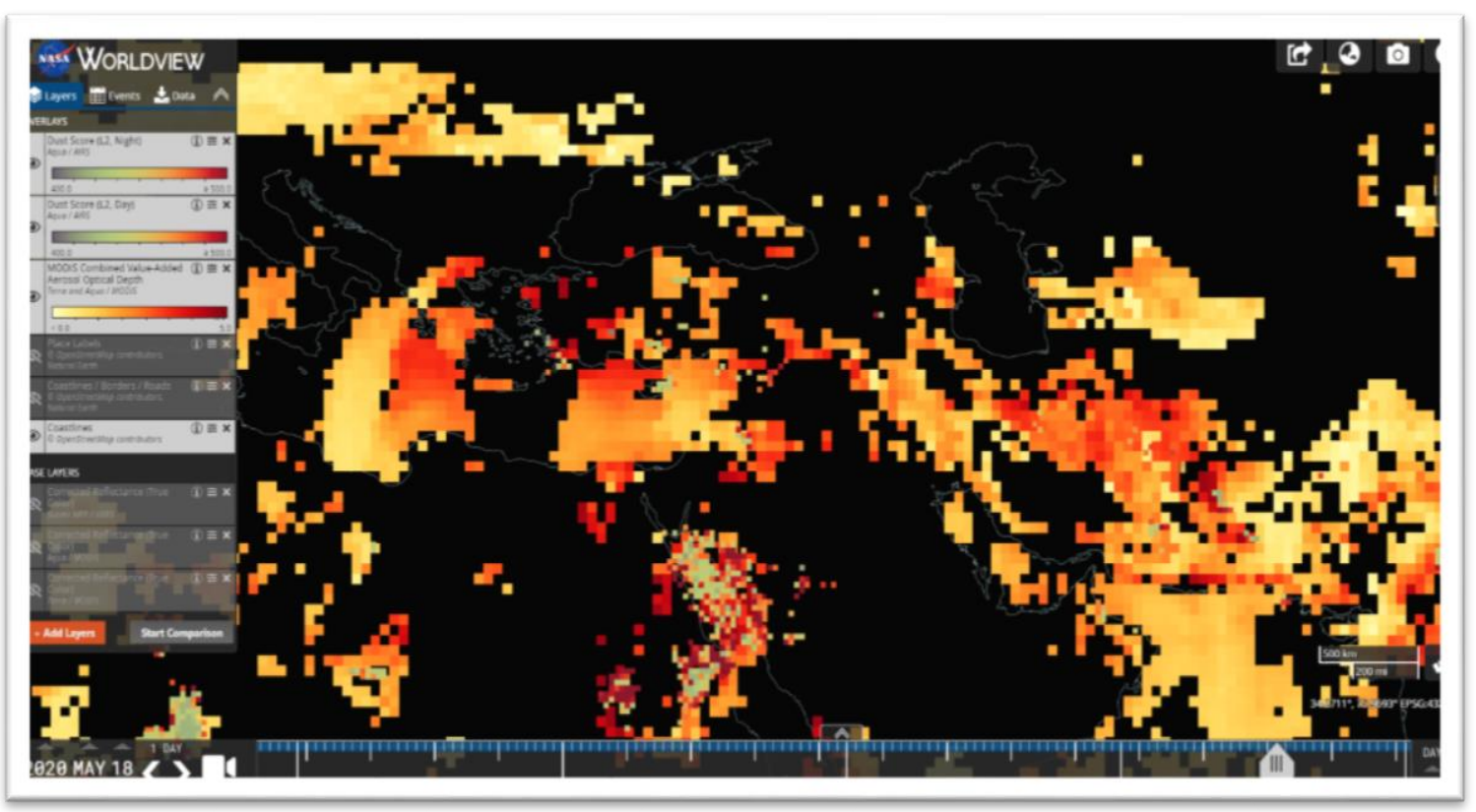

Figure 2:

Dust score and aerosol optic depth of Turkey and the neighbor countries for 18 May 2020

(NASA, 2020) 
In Figure 3, a dust surface mass map of Turkey and neighbor countries for 18 May 2020 was given. This map points that there was a huge dust storm formed in the Middle East and Northern Africa. Turkey and other closed countries are affected by the impacts of the dust storm. Thus, the Selçuklu district of Konya which is one of the most affected cities of Turkey from this dust storm was selected as a study area.

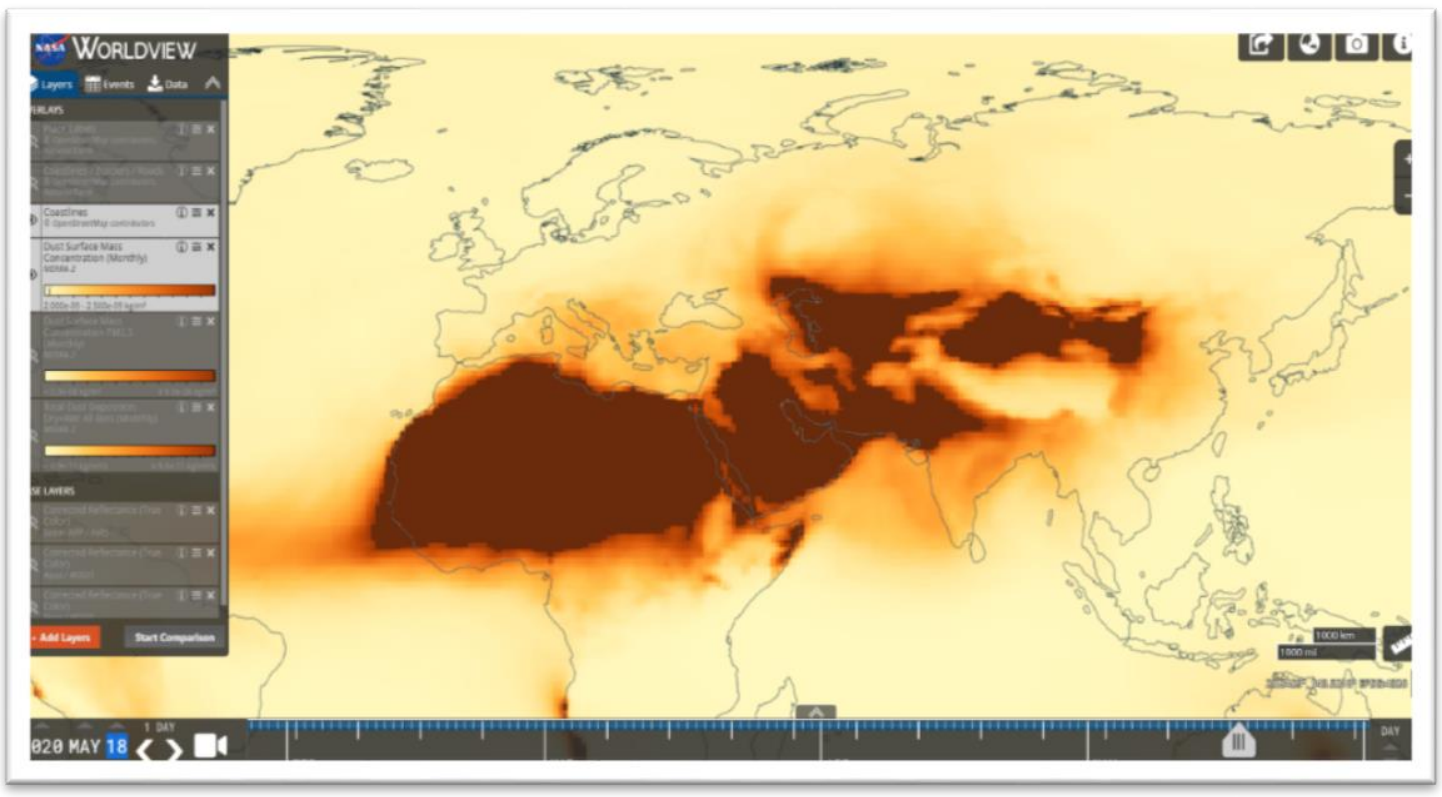

Figure 3:

Dust surface mass map of Turkey and the neighbor countries for 18 May 2020 (NASA, 2020)

There are two different measurement location presents in this study. To understand the correction of the personal measurements in one location (personal measurement point), the data taken from nearby measurement station (ministry measurement point) affiliated by Ministry of Environment and Urbanization was used. Figure 4 shows the map of Turkey, the map of Konya and Selçuklu District, and the location of the measurement point and monitoring station. According to Figure 4 (c) locations of the personal measurement point and ministry measurement point are found in the same latitude and they are very close to each other. 


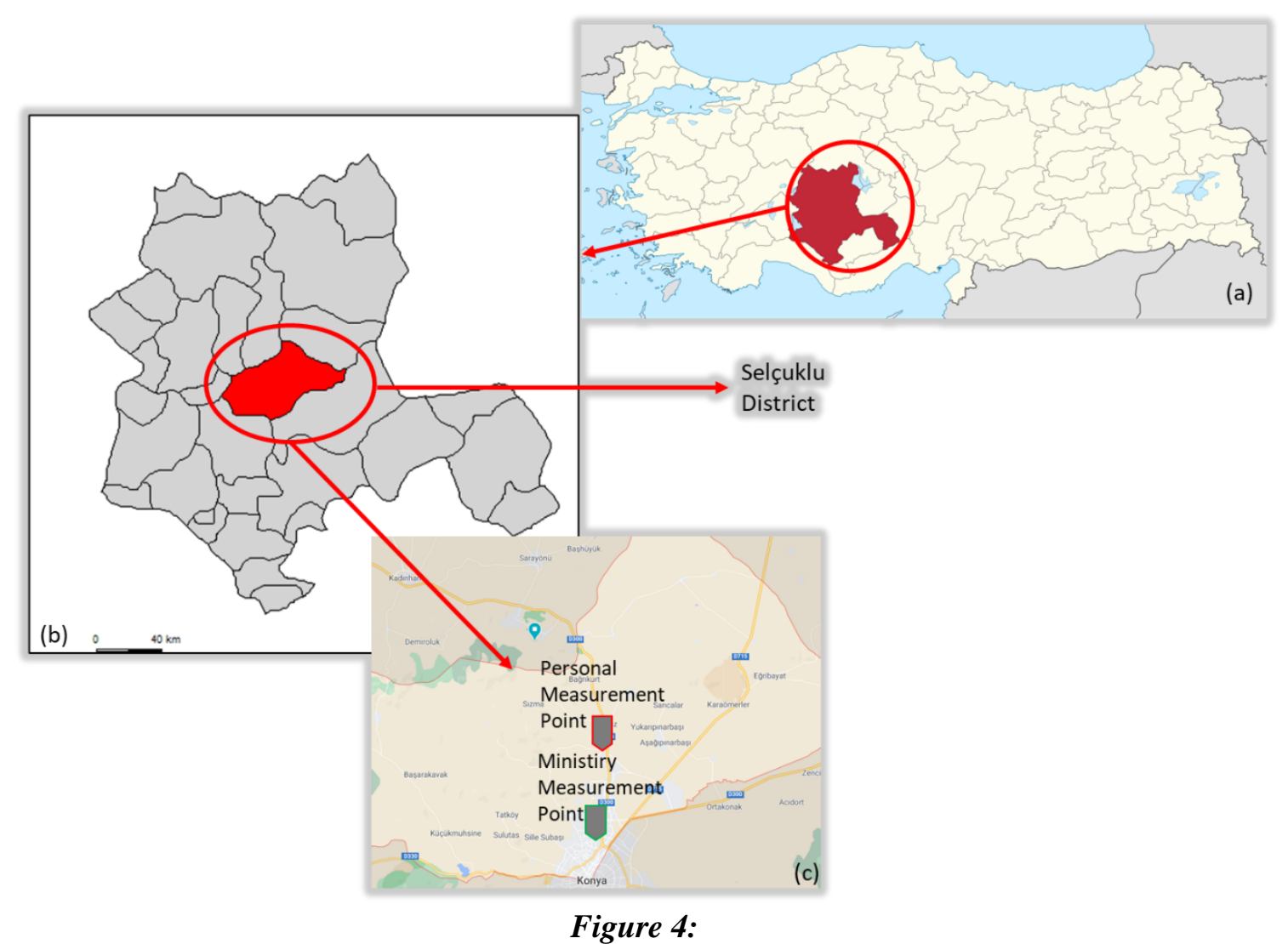

(a) Map of Turkey, (b) map of Konya and Selçuklu District, (c) locations of the personal measurement point and ministry measurement point (Anonymous-1, 2020; Anonymous-2, 2020;

Google Map, 2020)

\subsection{Statistical Analysis}

\subsubsection{Pearson Correlation Test}

Pearson correlation test was applied to all data including both measured and taken from the monitoring station. This test mainly explains the linear relationship between pairs of continuous variables. The coefficient called "r" represents the strength of this relationship. The Pearson correlation coefficient for two different parameters ( $a$ and $b$ ) is computed as equation 1 . This coefficient may only take values between -1 and +1 . The sign of this coefficient indicates the relationship's direction. The strength of this relation is indicated with the magnitude of the $r$ value that is the closeness to -1 and +1 .

$$
r=r_{a b}=\frac{\operatorname{cov}(a, b)}{\sqrt{\operatorname{var}(a)} * \sqrt{\operatorname{var}(b)}}
$$

"- 1 " represents the perfect negative linear relationship, 0 represents no relationship and "+1" represents the perfectly positive linear relationship (Anonymous-3, 2020). In Table 1, the ranges of $r$ values and represented strengths of these ranges is showed. (Ratner, 2009). 
Table 1. Strength of the relationship between variables with respect to $r$

\begin{tabular}{l|l} 
Ranges of $r$ values & Strength of the relationship \\
\hline $0.00-0.30$ & Weak \\
$0.30-0.70$ & Moderate \\
$0.70-1.00$ & Strong
\end{tabular}

\subsubsection{Multiple Linear Regression}

Two different multiple linear regression analysis was conducted for measured values of $\mathrm{PM}_{2.5}$ and $\mathrm{PM}_{10}$ together with the meteorological and pollution data taken from the monitoring station. In Table 2 and Table 3, variables entered into the regression models were given. Measured $\mathrm{PM}_{2.5}$ and $\mathrm{PM}_{10}$ were used as dependent variables and atmospheric pressure, air temperature, wind direction, $\mathrm{CO}$ concentration, $\mathrm{SO}_{2}$ concentration, wind speed, and relative humidity taken from AQMS were used as independent variables for each model. The results of these models show how many percent of the variance of the dependent variable was explained by the independent variables.

Table 2. Variables entered to the regression model for measured $\mathbf{P M}_{2.5}$

\begin{tabular}{ll}
\hline Model & \multicolumn{1}{c}{ Variables Entered } \\
\hline 1 & $\left(\mathrm{PM}_{2.5}\right) \mathrm{M}^{\mathrm{a}}, \mathrm{CO}$, Pressure $(\mathrm{P})$, Air temperature (AT), Wind direction (WD), $\mathrm{SO}_{2}$, Wind \\
speed (WS), Relative humidity (RH)
\end{tabular}

Table 3. Variables entered to the regression model for measured $\mathbf{P M}_{10}$

\begin{tabular}{ll}
\hline Model & \multicolumn{1}{c}{ Variables Entered } \\
\hline 1 & $\left(\mathrm{PM}_{10}\right) \mathrm{M}^{\mathrm{a}}, \mathrm{CO}$, Pressure $(\mathrm{P})$, Air temperature $(\mathrm{AT})$, Wind direction $(\mathrm{WD}), \mathrm{SO}_{2}$, \\
& Wind speed (WS), Relative humidity (RH) \\
\hline \multicolumn{2}{c}{${ }^{a .}$ Dependent Variable: Measured $P M_{10}\left[\left(P M_{10}\right) M\right]$}
\end{tabular}

\subsubsection{Principal Component Analysis}

The data with several variables can be classified with the help of principal component analysis (PCA) which is known as the most useful and common method for revealing the potential structure of the data set. PCA method mainly transforms the variables in a huge data set to smaller independent data sets called principal components. The linear combinations of the original variables from huge data are used to create uncorrelated and orthogonal principal components (Azid et al., 2014).

In this study, PCA was applied on 9 components (measured $\mathrm{PM}_{10}$, measured $\mathrm{PM}_{2.5}$, monitored $\mathrm{PM}_{10}, \mathrm{SO}_{2}, \mathrm{CO}$, wind speed, air temperature, relative humidity, atmospheric pressure, and wind direction) together. Before the PCA analysis, z scores were calculated by SPSS to normalize the data. Kaiser-Meyer-Olkin (KMO) and Bartlett's Test were applied to the data to understand the usability of the data for PCA. KMO measure of sampling adequacy represents the proportion caused by underlying factors and bigger than 0.5 represents that data is useful to be used in factor analysis. Besides, Bartlett's test of sphericity indicates the relation of the variables, and significance which is smaller than 0.05 represents that data is appropriate for the factor analysis (IBM Knowledge Center, 2020) 
During PCA analysis, the rotation method was selected as Kaiser-Varimax rotation. This method increases the factor loading by maximizing the variance squared loadings. This method highlights the small number of variables and the results may be easily interpreted (Anonymous4, 2020).

\subsubsection{Graphical Comparison}

All data used in this study were compared with each other on the graph during 10 days of monitoring. Moreover, $\mathrm{PM}_{10}$ data measured during 10 days between 16-26 ${ }^{\text {th }}$ May 2020 was compared with the data of previous years $(2015,2016,2017,2018)$ from the same monitoring station used in the analysis. These graphical comparisons explain the increase at $\mathrm{PM}_{10}$ levels during this period concerning other parameters and previous years.

\section{RESULTS AND DISCUSSION}

\subsection{Pearson Correlation Test Results}

Pearson correlation test result of all variables including measured and station data is given in Table 4. It explains that there was a medium positive relationship between measured $\left(\left(\mathrm{PM}_{10}\right) \mathrm{M}\right)$ and station (PM_10) $\mathrm{PM}_{10}$ pollution data. Moreover, strong positive relationships were detected between measured $\mathrm{PM}_{10}$ and measured PM2.5 ((PM2.5)M). Air temperature also showed a medium positive relationship with $(\mathrm{PM} 10) \mathrm{M},\left(\mathrm{PM}_{2.5}\right) \mathrm{M}$, and PM_10 and a strong negative relationship with relative humidity. Similar to $\left(\mathrm{PM}_{10}\right) \mathrm{M}, \mathrm{PM} \_10$ had a medium positive relationship with $\left(\mathrm{PM}_{10}\right) \mathrm{M},\left(\mathrm{PM}_{2.5}\right) \mathrm{M}$, and AT.

These results indicate that the measurements made by personal measurement device and measurements of ministry's monitoring station were compatible with each other. Therefore, in regression models and PCA analysis personal measurement data and meteorological data from monitoring station were used together. Moreover, the correlation between the parameters were also supports the results of multiple linear regression and PCA.

Table 4. Pearson correlation test results for the measured and station data

\begin{tabular}{|c|c|c|c|c|c|c|c|c|c|c|c|}
\hline & & $\left(\mathrm{PM}_{10}\right) \mathrm{M}$ & $\mathrm{PM}_{10}$ & $\mathrm{SO}_{2}$ & $\mathrm{CO}$ & WS & AT & $\mathrm{RH}$ & $\mathrm{P}$ & WD & $\begin{array}{c}\left(\mathrm{PM}_{2.5}\right) \\
\mathrm{M}\end{array}$ \\
\hline \multirow[t]{3}{*}{$\begin{array}{l}\left(\mathrm{PM}_{10}\right) \\
\mathrm{M}\end{array}$} & $\begin{array}{l}\text { Pearson } \\
\text { Correlation }\end{array}$ & 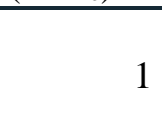 & $\begin{array}{r}.668 * \\
*\end{array}$ & $\begin{array}{r}.293 * \\
*\end{array}$ & $\begin{array}{r}0.06 \\
8\end{array}$ & $\begin{array}{r}.276^{*} \\
*\end{array}$ & $\begin{array}{r}.673 * \\
*\end{array}$ & $\begin{array}{r}.426 * \\
*\end{array}$ & 0.04 & $\begin{array}{r}.203^{*} \\
*\end{array}$ & $.972 * *$ \\
\hline & $\begin{array}{l}\text { Sig. (2- } \\
\text { tailed) }\end{array}$ & & 0 & 0 & $\begin{array}{r}0.28 \\
1\end{array}$ & 0 & 0 & 0 & 0.523 & 0.001 & 0 \\
\hline & $\mathrm{N}$ & 254 & 254 & 254 & 254 & 254 & 254 & 254 & 254 & 254 & 254 \\
\hline \multirow[t]{3}{*}{$\mathrm{PM}_{10}$} & $\begin{array}{l}\text { Pearson } \\
\text { Correlation }\end{array}$ & $.668 * *$ & 1 & $\begin{array}{r}.296 * \\
*\end{array}$ & $\begin{array}{r}0.09 \\
1\end{array}$ & $\begin{array}{r}- \\
.395 * \\
*\end{array}$ & $\begin{array}{r}.632 * \\
*\end{array}$ & $\begin{array}{r}- \\
.248^{*} \\
*\end{array}$ & 0.035 & $\begin{array}{r}.200 * \\
*\end{array}$ & $.678 * *$ \\
\hline & $\begin{array}{l}\text { Sig. (2- } \\
\text { tailed) }\end{array}$ & 0 & & 0 & $\begin{array}{r}0.14 \\
7\end{array}$ & 0 & 0 & 0 & 0.58 & 0.001 & 0 \\
\hline & $\mathrm{N}$ & 254 & 254 & 254 & 254 & 254 & 254 & 254 & 254 & 254 & 254 \\
\hline \multirow[t]{2}{*}{$\mathrm{SO}_{2}$} & $\begin{array}{l}\text { Pearson } \\
\text { Correlation }\end{array}$ & $.293 * *$ & $\begin{array}{r}.296 * \\
*\end{array}$ & 1 & 0.05 & $\begin{array}{r}- \\
.271 * \\
*\end{array}$ & $\begin{array}{r}.181 * \\
*\end{array}$ & -0.119 & $\begin{array}{r}.278^{*} \\
*\end{array}$ & $-.142 *$ & $.248 * *$ \\
\hline & $\begin{array}{l}\text { Sig. (2- } \\
\text { tailed) }\end{array}$ & 0 & 0 & & $\begin{array}{r}0.42 \\
4\end{array}$ & 0 & 0.004 & 0.059 & 0 & 0.024 & 0 \\
\hline
\end{tabular}


Uludağ University Journal of The Faculty of Engineering, Vol. 26, No. 2, 2021

\begin{tabular}{|c|c|c|c|c|c|c|c|c|c|c|c|}
\hline & $\mathrm{N}$ & 254 & 254 & 254 & 254 & 254 & 254 & 254 & 254 & 254 & 254 \\
\hline \multirow[t]{3}{*}{$\mathrm{CO}$} & $\begin{array}{l}\text { Pearson } \\
\text { Correlation }\end{array}$ & 0.068 & 0.091 & -0.05 & 1 & 0.117 & -0.094 & $.158^{*}$ & 0.048 & 0.104 & 0.08 \\
\hline & $\begin{array}{l}\text { Sig. (2- } \\
\text { tailed) }\end{array}$ & 0.281 & 0.147 & 0.424 & & 0.064 & 0.137 & 0.012 & 0.445 & 0.099 & 0.205 \\
\hline & $\mathrm{N}$ & 254 & 254 & 254 & 254 & 254 & 254 & 254 & 254 & 254 & 254 \\
\hline \multirow[t]{3}{*}{ WS } & $\begin{array}{l}\text { Pearson } \\
\text { Correlation }\end{array}$ & $-.276^{* *}$ & $\begin{array}{r}- \\
.395 * \\
*\end{array}$ & $\begin{array}{r}- \\
.271 * \\
*\end{array}$ & $\begin{array}{r}0.11 \\
7\end{array}$ & 1 & -0.086 & -0.077 & $\begin{array}{r}.320 * \\
*\end{array}$ & $\begin{array}{r}.209 * \\
*\end{array}$ & $-.296^{* *}$ \\
\hline & $\begin{array}{l}\text { Sig. (2- } \\
\text { tailed) }\end{array}$ & 0 & 0 & 0 & $\begin{array}{r}0.06 \\
4 \\
\end{array}$ & & 0.172 & 0.223 & 0 & 0.001 & 0 \\
\hline & $\mathrm{N}$ & 254 & 254 & 254 & 254 & 254 & 254 & 254 & 254 & 254 & 254 \\
\hline \multirow[t]{3}{*}{ AT } & $\begin{array}{l}\text { Pearson } \\
\text { Correlation }\end{array}$ & $.673 * *$ & $\begin{array}{r}.632 * \\
*\end{array}$ & $\begin{array}{r}.181 * \\
*\end{array}$ & $\begin{array}{r}0.09 \\
4\end{array}$ & 0.086 & 1 & $\begin{array}{r}.817 * \\
*\end{array}$ & 0.057 & $\begin{array}{r}.211^{*} \\
*\end{array}$ & $.679 * *$ \\
\hline & $\begin{array}{l}\text { Sig. (2- } \\
\text { tailed) }\end{array}$ & 0 & 0 & 0.004 & $\begin{array}{r}0.13 \\
7\end{array}$ & 0.172 & & 0 & 0.365 & 0.001 & 0 \\
\hline & $\mathrm{N}$ & 254 & 254 & 254 & 254 & 254 & 254 & 254 & 254 & 254 & 254 \\
\hline \multirow[t]{3}{*}{$\mathrm{RH}$} & $\begin{array}{l}\text { Pearson } \\
\text { Correlation }\end{array}$ & $-.426 * *$ & $\begin{array}{r}- \\
.248^{*} \\
*\end{array}$ & -0.119 & $\begin{array}{r}.158 \\
*\end{array}$ & 0.077 & $\begin{array}{r}- \\
.817^{*} \\
*\end{array}$ & 1 & -0.015 & $\begin{array}{r}.209 * \\
*\end{array}$ & $-.418 * *$ \\
\hline & $\begin{array}{l}\text { Sig. (2- } \\
\text { tailed) }\end{array}$ & 0 & 0 & 0.059 & $\begin{array}{r}0.01 \\
2 \\
\end{array}$ & 0.223 & 0 & & 0.818 & 0.001 & 0 \\
\hline & $\mathrm{N}$ & 254 & 254 & 254 & 254 & 254 & 254 & 254 & 254 & 254 & 254 \\
\hline \multirow[t]{3}{*}{$\mathrm{P}$} & $\begin{array}{l}\text { Pearson } \\
\text { Correlation }\end{array}$ & 0.04 & 0.035 & $\begin{array}{r}.278^{*} \\
*\end{array}$ & $\begin{array}{r}0.04 \\
8\end{array}$ & $\begin{array}{r}- \\
.320 * \\
*\end{array}$ & 0.057 & -0.015 & 1 & $\begin{array}{r}.183^{*} \\
*\end{array}$ & 0.053 \\
\hline & $\begin{array}{l}\text { Sig. (2- } \\
\text { tailed) }\end{array}$ & 0.523 & 0.58 & 0 & $\begin{array}{r}0.44 \\
5 \\
\end{array}$ & 0 & 0.365 & 0.818 & & 0.003 & 0.403 \\
\hline & $\mathrm{N}$ & 254 & 254 & 254 & 254 & 254 & 254 & 254 & 254 & 254 & 254 \\
\hline \multirow[t]{3}{*}{ WD } & $\begin{array}{l}\text { Pearson } \\
\text { Correlation }\end{array}$ & $-.203 * *$ & $\begin{array}{r}- \\
.200 * \\
*\end{array}$ & $-.142 *$ & $\begin{array}{r}0.10 \\
4\end{array}$ & $\begin{array}{r}.209 * \\
*\end{array}$ & $\begin{array}{r}- \\
.211^{*} \\
*\end{array}$ & $\begin{array}{r}.209 * \\
*\end{array}$ & $\begin{array}{r}.183 * \\
*\end{array}$ & 1 & $-.182 * *$ \\
\hline & $\begin{array}{l}\text { Sig. (2- } \\
\text { tailed) }\end{array}$ & 0.001 & 0.001 & 0.024 & $\begin{array}{r}0.09 \\
9 \\
\end{array}$ & 0.001 & 0.001 & 0.001 & 0.003 & & 0.004 \\
\hline & $\mathrm{N}$ & 254 & 254 & 254 & 254 & 254 & 254 & 254 & 254 & 254 & 254 \\
\hline \multirow[t]{3}{*}{$\begin{array}{l}\left(\mathrm{PM}_{2.5}\right) \\
\mathrm{M}\end{array}$} & $\begin{array}{l}\text { Pearson } \\
\text { Correlation }\end{array}$ & $.972 * *$ & $\begin{array}{r}.678 * \\
*\end{array}$ & $\begin{array}{r}.248 * \\
*\end{array}$ & 0.08 & $\begin{array}{r}.296^{*} \\
*\end{array}$ & $\begin{array}{r}.679 * \\
*\end{array}$ & $\begin{array}{r}.418 * \\
*\end{array}$ & 0.053 & $\begin{array}{r}- \\
.182 * \\
*\end{array}$ & 1 \\
\hline & $\begin{array}{l}\text { Sig. (2- } \\
\text { tailed) }\end{array}$ & 0 & 0 & 0 & $\begin{array}{r}0.20 \\
5\end{array}$ & 0 & 0 & 0 & 0.403 & 0.004 & \\
\hline & $\mathrm{N}$ & 254 & 254 & 254 & 254 & 254 & 254 & 254 & 254 & 254 & 254 \\
\hline
\end{tabular}

\subsection{Multiple Linear Regression Results}

Model summary of multiple linear regression for measured $\mathrm{PM}_{2.5}$ pollution is given in Table 5. Because of the units of independent variables, the adjusted $R$ square value explains the 
regression results. This result indicates that the independent variables explain $57.3 \%$ of the variance of the dependent variable $\left(\mathrm{PM}_{2.5}\right)$.

Table 5. Model summary of multiple linear regression for measured $\mathbf{P M}_{2.5}$ pollution

\begin{tabular}{lrrrr}
\hline Model & R & R Square & Adjusted R Square & Std. Error of the Estimate \\
\hline 1 & $.765^{\mathrm{a}}$ & .585 & .573 & 317.21273 \\
\hline
\end{tabular}

The coefficients and significance of the independent variables on $\mathrm{PM}_{2.5}$ pollution were explained in Table 6. Wind speed, air temperature, relative humidity, and CO concentrations were found significant, and they explain the change in dependent variable differently. Wind speed affects the dependent variable negatively with a standardized beta coefficient of -0.225 . Air temperature, relative humidity, and $\mathrm{CO}$ concentrations affect $\mathrm{PM}_{2.5}$ pollution positively with $0.890,0.276$, and 0.154 standardized beta coefficients, respectively.

Table 6. Standardized beta coefficients and significance of independent variables with respect to dependent variable $\left(\mathbf{P M}_{2.5}\right)$

\begin{tabular}{|c|c|c|c|c|c|c|c|c|c|c|}
\hline \multirow[b]{2}{*}{ Model } & \multicolumn{2}{|c|}{$\begin{array}{l}\text { Unstandardized } \\
\text { Coefficients }\end{array}$} & \multicolumn{3}{|c|}{$\begin{array}{l}\text { Standardized } \\
\text { Coefficients }\end{array}$} & \multicolumn{3}{|c|}{ Correlations } & \multicolumn{2}{|c|}{$\begin{array}{c}\text { Collinearity } \\
\text { Statistics }\end{array}$} \\
\hline & B & Std. Error & Beta & $\mathrm{t}$ & Sig. & $\begin{array}{l}\text { Zero- } \\
\text { order }\end{array}$ & $\begin{array}{c}\text { Partia } \\
1\end{array}$ & Part & $\begin{array}{c}\text { Toleranc } \\
\mathrm{e}\end{array}$ & VIF \\
\hline 1 (Consta & $\begin{array}{r}10451.75 \\
7\end{array}$ & 5173.472 & & 2.020 & $\begin{array}{r}0.04 \\
4\end{array}$ & & & & & \\
\hline Wind & -118.287 & 25.317 & .225 & 672 & 0,00 & -0.296 & 0.285 & 0.192 & 0.725 & 1.379 \\
\hline Air te & 57.492 & 4.810 & 0.89 & 11.952 & 0,00 & 0.679 & 0.606 & 0.491 & 0.304 & 3.286 \\
\hline Rel humidity & 10.752 & 2.950 & 0.276 & 3.645 & 0,00 & -0.418 & 0.226 & 0.15 & 0.295 & 3.392 \\
\hline Pressure & -12.568 & 5.732 & -0.103 & -2.193 & $\begin{array}{r}0.02 \\
9\end{array}$ & 0.053 & 0.138 & -0.09 & 0.77 & 1.298 \\
\hline Wind & .086 & .341 & 0.012 & .254 & 0.8 & -0.182 & 0.016 & 0.01 & 0.817 & 1.224 \\
\hline $\mathrm{SO}_{2}$ & 2.925 & 1.357 & 0.096 & 2.155 & $\begin{array}{r}0.03 \\
2\end{array}$ & 0.248 & 0.136 & 0.089 & 0.848 & 1.179 \\
\hline $\mathrm{CO}$ & .154 & .042 & 0.154 & 3.636 & 0,00 & 0.08 & 0.226 & 0.149 & 0.938 & 1.066 \\
\hline
\end{tabular}

Model summary of multiple linear regression for measured $\mathrm{PM}_{10}$ pollution is given in Table 7. According to Table 7, the independent variables explain $57.3 \%$ of the variance of the dependent variable $\left(\mathrm{PM}_{10}\right)$

Table 7. Model summary of multiple linear regression for measured $\mathbf{P M}_{10}$ pollution

\begin{tabular}{lrrrr}
\hline Model & R & R Square & Adjusted R Square & Std. Error of the Estimate \\
\hline 1 & $.756^{\mathrm{a}}$ & .571 & .559 & 32.90789 \\
\hline
\end{tabular}

In Table 8 coefficients and significance of independent variable for pollution are given. Wind speed, air temperature, relative humidity, $\mathrm{SO}_{2}$, and $\mathrm{CO}$ concentrations were found significant. Wind speed explains the change in PM10 pollution negatively with a standardized beta coefficient of -0.194. Air temperature, relative humidity, $\mathrm{SO}_{2}$, and $\mathrm{CO}$ concentrations explain the change in $\mathrm{PM}_{10}$ positively with a standardized beta coefficient of $0.851,0.250,0.153$ and 0.143 , respectively. 
Table 8. Standardized beta coefficients and significance of independent variables with respect to dependent variable $\left(\mathrm{PM}_{10}\right)$

\begin{tabular}{|c|c|c|c|c|c|c|c|c|c|c|}
\hline \multirow[b]{2}{*}{ Model } & \multicolumn{2}{|c|}{$\begin{array}{l}\text { Unstandardized } \\
\text { Coefficients }\end{array}$} & \multicolumn{3}{|c|}{$\begin{array}{l}\text { Standardized } \\
\text { Coefficients }\end{array}$} & \multicolumn{3}{|c|}{ Correlations } & \multicolumn{2}{|c|}{$\begin{array}{l}\text { Collinearity } \\
\text { Statistics }\end{array}$} \\
\hline & B & $\begin{array}{l}\text { Std. } \\
\text { Error }\end{array}$ & Beta & $\mathrm{t}$ & Sig. & $\begin{array}{l}\text { Zero- } \\
\text { order }\end{array}$ & Partial & Part & Tolerance & VIF \\
\hline 1 (Constant) & 1217.401 & 536.700 & & 2.268 & .024 & & & & & \\
\hline Wind speed & -10.408 & 2.626 & .194 & -3.963 & .000 & -.276 & -.245 & .165 & .725 & 1.379 \\
\hline Air temperature & 5.614 & .499 & .851 & 11.250 & .000 & .673 & .583 & .470 & .304 & 3.286 \\
\hline Rel humidity & .996 & .306 & .250 & 3.254 & .001 & -.426 & .203 & .136 & .295 & 3.392 \\
\hline Pressure & -1.440 & .595 & $.115^{-}$ & -2.421 & .016 & .040 & -.153 & .101 & .770 & 1.298 \\
\hline Wind direction & -.006 & .035 & .008 & -.169 & .866 & -.203 & -.011 & .007 & .817 & 1.224 \\
\hline $\mathrm{SO}_{2}$ & .476 & .141 & .153 & 3.384 & .001 & .293 & .211 & .141 & .848 & 1.179 \\
\hline $\mathrm{CO}$ & .015 & .004 & .145 & 3.358 & .001 & .068 & .209 & .140 & .938 & 1.066 \\
\hline
\end{tabular}

The study made by Fong et al. $\mathrm{PM}_{10}$ were forecasted by multiple linear regression with independent variables such as $\mathrm{CO}, \mathrm{NO}_{2}, \mathrm{SO}_{2}$, ambient temperature, relative, humidity, wind speed, Mean Sea Level Pressure and rainfall amount. $\mathrm{R}^{2}$ value was found as 0.715 and major positive contributors was found as $\mathrm{CO}, \mathrm{SO}_{2}$, temperature, pressure and negative contributors was found as relative humidity and rainfall (Fong et al. 2018). In another study conducted by Çelik and Kad1, relation between PM pollution and meteorological factors was determined. The results show that temperature, wind speed and humidity affected PM pollution negatively with $\mathrm{R}^{2}$ of 0.661 (Çelik and Kad1, 2007). Study of Sritong-aon et al. applied multiple linear regression on PM pollution and meteorological factors and found that PM pollution was affected negatively form temperature, relative humidity, wind speed and rainfall and positively from pressure and fire hotspots (Sritong-aon et al., 2021).

The multiple linear regression models in this study had given similar results with previous works. Meteorological factors have significant effect on PM pollution. With respect to the climatic features of the study area, the effects of the parameters change.

\subsection{Principal Component Analysis Results}

To evaluate the suitability of the data for factor analysis, KMO and Bartlett's test was applied. The results of KMO and Bartlett's test are given in Table 9. KMO measure of sampling adequacy value was found as 0.636 which is greater than 0.5 indicating the suitability of data for PCA. Also, the significance of Bartlett's test of sphericity was found as 0.000 .

Table 9. KMO and Bartlett's Test results

\begin{tabular}{llr} 
Kaiser-Meyer-Olkin Measure of Sampling Adequacy. & .636 \\
\hline $\begin{array}{l}\text { Bartlett's Test of } \\
\text { Sphericity }\end{array}$ & Approx. Chi-Square & 1388.435 \\
\cline { 2 - 3 } & df & 36 \\
\hline
\end{tabular}

Table 10 shows that the total variance explained by PCA and cumulative percent of loading. According to this table, 4 principal components (PC) were detected, and cumulatively $78.108 \%$ percent of the total variance was explained by these components. $32.716 \%$ of the total variance 
was explained by PC1, $19.335 \%$ was explained by PC2, $13.275 \%$ was explained by PC 3 and $12.782 \%$ was explained by PC4.

Table 10. Total variance explained by PCA

\begin{tabular}{|c|c|c|c|c|c|c|c|c|c|}
\hline \multirow[b]{2}{*}{$\begin{array}{l}\text { Compone } \\
\text { nt }\end{array}$} & \multicolumn{3}{|c|}{ Initial Eigenvalues } & \multicolumn{3}{|c|}{$\begin{array}{l}\text { Extraction Sums of } \\
\text { Squared Loadings }\end{array}$} & \multicolumn{3}{|c|}{$\begin{array}{c}\text { Rotation Sums of Squared } \\
\text { Loadings }\end{array}$} \\
\hline & $\begin{array}{c}\text { Tota } \\
1\end{array}$ & $\begin{array}{c}\% \text { of } \\
\text { Varianc } \\
\mathrm{e}\end{array}$ & $\begin{array}{c}\text { Cumulati } \\
\text { ve } \%\end{array}$ & $\begin{array}{c}\text { Tota } \\
1\end{array}$ & $\begin{array}{c}\% \text { of } \\
\text { Varianc } \\
\mathrm{e}\end{array}$ & $\begin{array}{c}\text { Cumulati } \\
\text { ve } \%\end{array}$ & $\begin{array}{c}\text { Tota } \\
1\end{array}$ & $\begin{array}{c}\% \text { of } \\
\text { Varianc } \\
\mathrm{e}\end{array}$ & $\begin{array}{c}\text { Cumulati } \\
\text { ve } \%\end{array}$ \\
\hline 1 & $\begin{array}{r}3.26 \\
1\end{array}$ & 36.237 & 36.237 & $\begin{array}{r}3.26 \\
1\end{array}$ & 36.237 & 36.237 & $\begin{array}{r}2.94 \\
4\end{array}$ & 32.716 & 32.716 \\
\hline 2 & $\begin{array}{r}1.52 \\
4\end{array}$ & 16.935 & 53.171 & $\begin{array}{r}1.52 \\
4\end{array}$ & 16.935 & 53.171 & $\begin{array}{r}1.74 \\
0\end{array}$ & 19.335 & 52.051 \\
\hline 3 & $\begin{array}{r}1.19 \\
6 \\
\end{array}$ & 13.294 & 66.465 & $\begin{array}{r}1.19 \\
6 \\
\end{array}$ & 13.294 & 66.465 & $\begin{array}{r}1.19 \\
5\end{array}$ & 13.275 & 65.326 \\
\hline 4 & $\begin{array}{r}1.04 \\
8\end{array}$ & 11.643 & 78.108 & $\begin{array}{r}1.04 \\
8\end{array}$ & 11.643 & 78.108 & $\begin{array}{r}1.15 \\
0\end{array}$ & 12.782 & 78.108 \\
\hline 5 & .775 & 8.614 & 86.721 & & & & & & \\
\hline 6 & .675 & 7.498 & 94.219 & & & & & & \\
\hline 7 & .371 & 4.120 & 98.339 & & & & & & \\
\hline 8 & .124 & 1.380 & 99.719 & & & & & & \\
\hline 9 & .025 & .281 & 100.000 & & & & & & \\
\hline
\end{tabular}

The rotated component matrix showing the clusters of components is given in Table 11. PC1 includes PM2.5, PM10, air temperature, and relative humidity which are evaluated in the same group. PC2 includes wind speed and $\mathrm{SO}_{2}$ pollution, and $\mathrm{PC} 3$ includes wind direction and pressure and PC4 includes $\mathrm{CO}$ concentration. The results of this analysis support the results of the Pearson correlation. Also, PM10 and PM2.5 pollution in that area is mainly affected by air temperature and relative humidity. Relative humidity has a negative effect on particulate matter while air temperature has a positive effect on PM concentrations. The component plot in the rotated space is given in Figure 5. In Figure 5, the appearance of the variables in 3D space was shown.

Table 11. Rotated component matrix of PCA

\begin{tabular}{|c|c|c|c|c|}
\hline & \multicolumn{4}{|c|}{ Component } \\
\hline & 1 & 2 & 3 & 4 \\
\hline Zscore(Airtemp) & .935 & .042 & -.017 & -.145 \\
\hline Zscore(Relhumid) & -.831 & .136 & -.043 & .360 \\
\hline Zscore(PM10)M & .813 & .316 & -.196 & .315 \\
\hline Zscore $\left(\mathrm{PM}_{2.5}\right) \mathrm{M}$ & .812 & .311 & -.181 & .331 \\
\hline Zscore(Windspeed) & .002 & -.822 & .213 & -.016 \\
\hline Zscore $\left(\mathrm{SO}_{2}\right)$ & .188 & .650 & .045 & -.083 \\
\hline Zscore(Winddirec) & -.148 & -.193 & .807 & .163 \\
\hline Zscore(Pressure) & .022 & .614 & .636 & -.051 \\
\hline Zscore $(\mathrm{CO})$ & -.018 & -.107 & .136 & .869 \\
\hline
\end{tabular}

Extraction Method: Principal Component Analysis.

Rotation Method: Varimax with Kaiser Normalization ${ }^{a}$

a. Rotation converged in 5 iterations. 


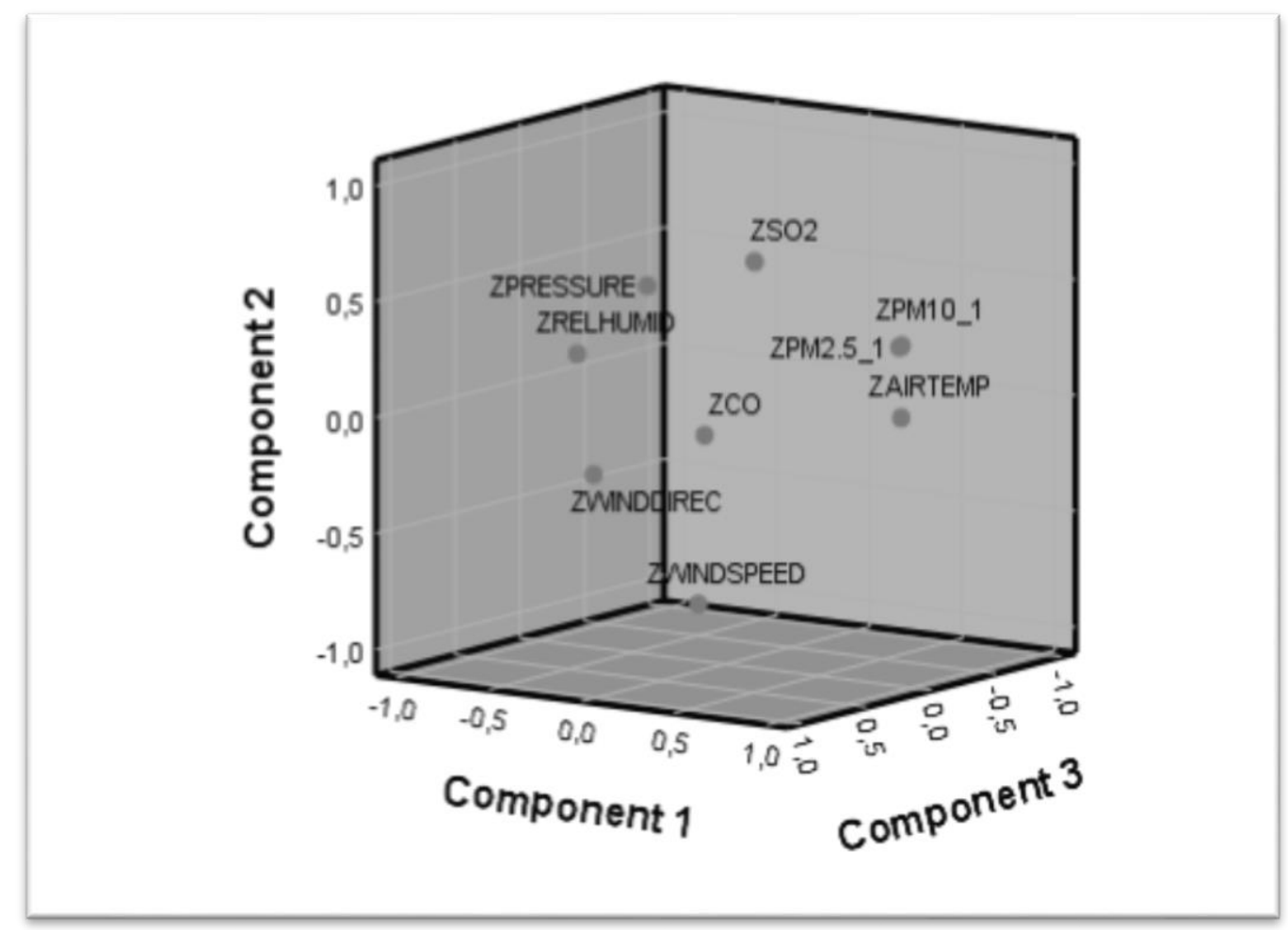

Figure 5:

Component plot in rotated space

Several studies were conducted about PCA application on understanding the effect of meteorological factors on particulate matter concentrations and source identification. In Table 12 the results of similar studies were compared with the results of this study on the application of PCA. According to this table, PM concentrations were generally grouped with other pollutants and some meteorological factors such as temperature, wind speed and relative humidity. PCA study conducted by Abdullah at al. resulted that $\mathrm{PM}_{10}$ pollution was grouped with other pollutants like $\mathrm{CO}, \mathrm{NO}_{2}$ which were represented as traffic originated emissions (Abdullah et al., 2018). Another study conducted by $\mathrm{Zu}$ 'ska et al. found that average, maximum and minimum temperature had the greatest effect on $\mathrm{PM}_{10}$ pollution (Zu'ska et al., 2019). Moreover, other study concluded that $\mathrm{PM}_{10}$ pollution is influenced positively from pressure (Fong et al., 2018). Comprehensive study conducted by Khan et al. aimed to identify potential sources of PM10 in the residential area. PCA study results showed that $\mathrm{PM}_{10}$ was mainly contributed by traffic emissions such as $\mathrm{O}_{3}, \mathrm{CO}, \mathrm{NO}_{\mathrm{x}}, \mathrm{NO}, \mathrm{NO}_{2}, \mathrm{SO}_{2}, \mathrm{CH}_{4}$ and nonmethane hydrocarbon (NMHC). The other PM10 source was identified as meteorological factors. Temperature and wind speed affected $\mathrm{PM}_{10}$ concentrations positively and relative humidity affected $\mathrm{PM}_{10}$ concentrations negatively. Last component of the study was detected as wind direction which has a negative impact on $\mathrm{PM}_{10}$ concentration levels (Khan et al., 2015). The study of Hashim also applied PCA on air pollution and meteorological data and found that $\mathrm{PM}_{10}, \mathrm{CO}, \mathrm{SO}_{2}$ were grouped in same component, and they had strongly positive relation with each other as a traffic emission (Hashim et al., 2018). The study conducted by Rahman et al. for Malaysia concluded that $\mathrm{PM}_{10}$ concentrations were affected positively by temperature and negatively by relative humidity (Rahman et al., 2015). When the results of this study were compared with the results of previous studies, it is concluded that PM pollutant concentrations were affected from meteorological factors such as temperature and relative humidity and similar results were found with other studies. Moreover, $\mathrm{SO}_{2}$ and $\mathrm{CO}$ were 
Kunt F., Ayturan Z.C. Dursun Ş.: Statis. Analy. Eval. of PM Concen. During the Dust Storms

not found contributing factors like some previous studies because the source of PM in this study is dust storm not traffic.

Table 12. Comparison of present study with similar studies on the application of PCA

\begin{tabular}{|c|c|c|c|c|c|c|}
\hline & Pollutants & $\begin{array}{l}\text { Meteorologic } \\
\text { al } \\
\text { Factors }\end{array}$ & $\begin{array}{l}\text { Components } \\
\text { Number }\end{array}$ & $\begin{array}{l}\text { Components } \\
\text { related to } \\
\text { PM }\end{array}$ & $\begin{array}{l}\% \text { of } \\
\text { Variance }\end{array}$ & Reference \\
\hline \multirow{4}{*}{$\begin{array}{l}\text { Similar } \\
\text { Studies }\end{array}$} & $\begin{array}{l}\mathrm{PM}_{10} \\
\mathrm{CO} \\
\mathrm{NO}_{2}\end{array}$ & $\begin{array}{c}\text { Wind Speed, } \\
\text { Ambient } \\
\text { Temperature, } \\
\text { Global } \\
\text { Radiation, } \\
\text { Rainfall } \\
\text { amount } \\
\text { Mean Sea } \\
\text { Level Pressure }\end{array}$ & 3 & $\begin{array}{c}\mathrm{PM}_{10} \\
\mathrm{CO} \\
\mathrm{NO}_{2} \\
\text { (positive) }\end{array}$ & 29.812 & $\begin{array}{c}\text { (Abdullah } \\
\text { et al., 2018) }\end{array}$ \\
\hline & $\mathrm{PM}_{10}$ & $\begin{array}{c}\text { Average, } \\
\text { Minimum, } \\
\text { Maximum } \\
\text { Temperature } \\
\text { Total } \\
\text { Precipitation } \\
\text { Relative } \\
\text { Humidity } \\
\text { Average and } \\
\text { Maximum } \\
\text { Wind Speed } \\
\text { Atmospheric } \\
\text { Pressure }\end{array}$ & 3 & $\begin{array}{c}\text { Average, } \\
\text { Minimum, } \\
\text { Maximum } \\
\text { Temperature } \\
\text { (positive) } \\
\mathrm{PM}_{10}\end{array}$ & 35 & $\begin{array}{l}\text { (Zu'ska et } \\
\text { al., 2019) }\end{array}$ \\
\hline & $\begin{array}{l}\mathrm{PM}_{10} \\
\mathrm{CO} \\
\mathrm{NO}_{2}\end{array}$ & $\begin{array}{c}\text { Wind speed } \\
\text { Temperature } \\
\text { Rainfall } \\
\text { Pressure } \\
\end{array}$ & 3 & $\begin{array}{c}\mathrm{PM}_{10} \\
\text { Pressure } \\
\text { (positive) }\end{array}$ & - & $\begin{array}{l}\text { (Fong et } \\
\text { al., 2018) }\end{array}$ \\
\hline & $\begin{array}{c}\mathrm{PM}_{10} \\
\mathrm{CO} \\
\mathrm{O}_{3} \\
\mathrm{NOx} \\
\mathrm{NO} \\
\mathrm{NO}_{2} \\
\mathrm{SO}_{2} \\
\mathrm{CH}_{4} \\
\text { Nonmethane } \\
\text { Hydrocarbon } \\
\text { (NMHC) }\end{array}$ & $\begin{array}{l}\text { Wind speed } \\
\text { Wind } \\
\text { direction } \\
\text { Temperature } \\
\text { Relative } \\
\text { Humidity }\end{array}$ & 3 & $\begin{array}{c}\text { Temperature } \\
\text { Wind speed } \\
\text { (positive) } \\
\text { Relative } \\
\text { Humidity } \\
\text { (negative) } \\
\\
\mathrm{CO} \\
\mathrm{O}_{3} \\
\mathrm{NOx} \\
\mathrm{NO} \\
\mathrm{NO}_{2} \\
\mathrm{SO}_{2} \\
\mathrm{CH}_{4} \\
\mathrm{NMHC} \\
\text { (positive) }\end{array}$ & 14 & $\begin{array}{l}\text { (Khan et } \\
\text { al., 2015) }\end{array}$ \\
\hline
\end{tabular}




\begin{tabular}{|c|c|c|c|c|c|c|}
\hline & & & & \multicolumn{2}{|l|}{$\begin{array}{c}\text { Wind } \\
\text { direction }\end{array}$} & \\
\hline & $\begin{array}{l}\mathrm{PM}_{10} \\
\mathrm{SO}_{2} \\
\mathrm{NO}_{2} \\
\mathrm{CO} \\
\end{array}$ & $\begin{array}{l}\text { Wind Speed } \\
\text { Ambient } \\
\text { Temperature } \\
\text { Humidity }\end{array}$ & 3 & $\begin{array}{c}\mathrm{PM}_{10} \\
\mathrm{CO} \\
\mathrm{SO}_{2}\end{array}$ & 29.420 & $\begin{array}{c}\text { (Hashim et } \\
\text { al., 2018) }\end{array}$ \\
\hline & $\begin{array}{c}\mathrm{PM}_{10} \\
\mathrm{CO} \\
\mathrm{O}_{3} \\
\mathrm{NO}_{2}\end{array}$ & $\begin{array}{c}\text { Relative } \\
\text { humidity - } \\
\text { Ambient } \\
\text { temperature } \\
\text { Wind velocity }\end{array}$ & 3 & $\begin{array}{c}\text { PM10 } \\
\text { Relative } \\
\text { humidity } \\
\text { (negative) } \\
\text { Ambient } \\
\text { temperature } \\
\text { (positive) }\end{array}$ & 17.15 & $\begin{array}{l}\text { (Rahman et } \\
\text { al., 2015) }\end{array}$ \\
\hline $\begin{array}{c}\text { Present } \\
\text { Study }\end{array}$ & $\begin{array}{l}\mathrm{PM}_{2.5} \\
\mathrm{PM}_{10} \\
\mathrm{SO}_{2} \\
\mathrm{CO}\end{array}$ & $\begin{array}{l}\text { Wind Speed } \\
\text { Air } \\
\text { Temperature } \\
\text { Relative } \\
\text { Humidity } \\
\text { Pressure } \\
\text { Wind } \\
\text { Direction }\end{array}$ & 4 & $\begin{array}{c}\mathrm{PM}_{2.5} \\
\mathrm{PM}_{10} \\
\text { Air } \\
\text { Temperature } \\
\text { (positive) } \\
\text { Relative } \\
\text { Humidity } \\
\text { (negative) }\end{array}$ & 32.716 & - \\
\hline
\end{tabular}

\subsection{Graphical Comparison Results}

The daily mean value of $\mathrm{PM}_{10}$ and $\mathrm{PM}_{2.5}$ measurements and monitoring station data during the measurement period (16-26 ${ }^{\text {th }}$ May 2020) was compared in Figure 6. According to this graph, Especially $\mathrm{PM}_{2.5}$ concentrations were detected very high until the $22^{\text {nd }}$ of May 2020. After that day, the $\mathrm{PM}_{2.5}$ concentrations decreased very sharply with the effect of rain and the effects of dust storm were passed away. Similarly, $\mathrm{PM}_{10}$ concentrations also decreased after the $22^{\text {nd }}$ of May. Air temperature showed a similar trend with PM concentrations, the decrease in the air temperature was detected after the $22^{\text {nd }}$ of May. Besides, relative humidity values increased after that day. However, the other parameters such as wind speed, wind direction, pressure, $\mathrm{SO}_{2}$, and $\mathrm{CO}$ concentrations showed different trends than PM concentrations, air temperature, and relative humidity. 


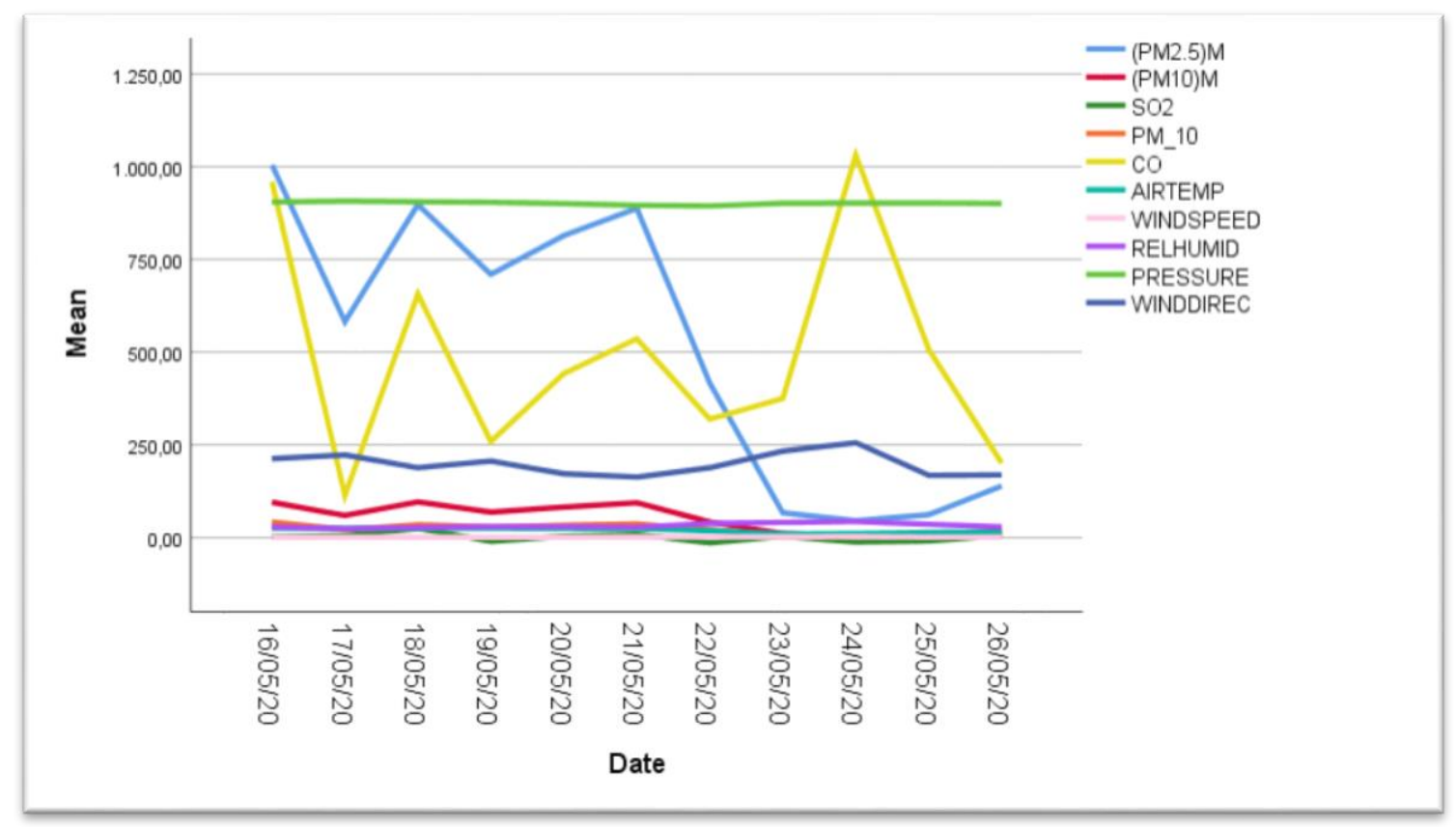

Figure 6:

Daily mean value comparison of hourly measurement of all data (The units of parameters: PM $\left(\mu \mathrm{g} / \mathrm{m}^{3}\right)$, wind speed $(\mathrm{m} / \mathrm{s})$, air temperature $\left({ }^{\circ} \mathrm{C}\right)$, relative humidity $(\%)$, pressure $(\mathrm{mbar})$, wind direction (degree), $\left.\mathrm{SO}_{2}\left(\mu \mathrm{g} / \mathrm{m}^{3}\right), \mathrm{CO}\left(\mu \mathrm{g} / \mathrm{m}^{3}\right)\right)$

Moreover, 24 hours limit value for $\mathrm{PM}_{10}\left(50 \mu \mathrm{g} / \mathrm{m}^{3}\right)$ by European Union (EU) Air Quality Standards under Directive 2008/50/EU was exceeded during 16-22 ${ }^{\text {th }}$ May 2020 (EU, 2020). 24 hours limit value for $\mathrm{PM}_{2.5}\left(25 \mu \mathrm{g} / \mathrm{m}^{3}\right)$ by World Health Organization (WHO)was also exceeded during 16-22 $2^{\text {th }}$ May 2020. These high levels of $\mathrm{PM}_{2.5}$ may be too dangerous for public health (WHO, 2018)

In previous years $\mathrm{PM}_{10}$ values were used to make comparisons about $\mathrm{PM}_{10}$ pollution during the measurement period. In Figures 7 and 8 , daily mean $\mathrm{PM}_{10}$ concentrations between 16 and $25^{\text {th }}$ May of previous years were compared with a daily mean value of 2020 measurements. The $\mathrm{PM}_{10}$ concentrations measured at $16-26^{\text {th }}$ May 2020 were detected significantly higher than the previous four years $(2015,2016,2017,2018)$ and the average of these years. These graphs prove that the extreme PM concentration increase was observed around the sampling area on 16-22 $2^{\text {th }}$ May 2020. 


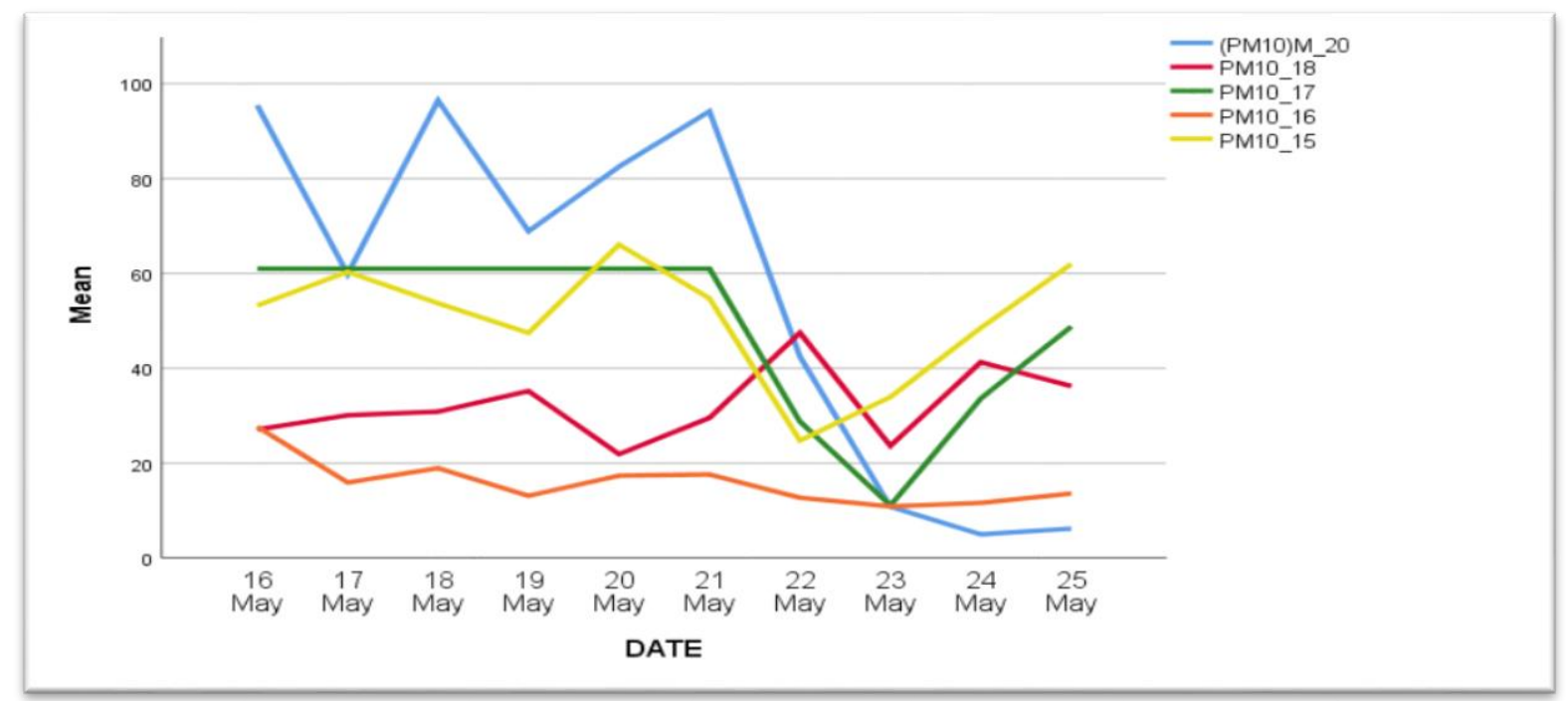

Figure 7:

Daily mean concentration $\left(\mu \mathrm{g} / \mathrm{m}^{3} P M_{10}\right)$ comparison of the measurement results of previous 4 year and 2020 measurement of $P M_{10}$

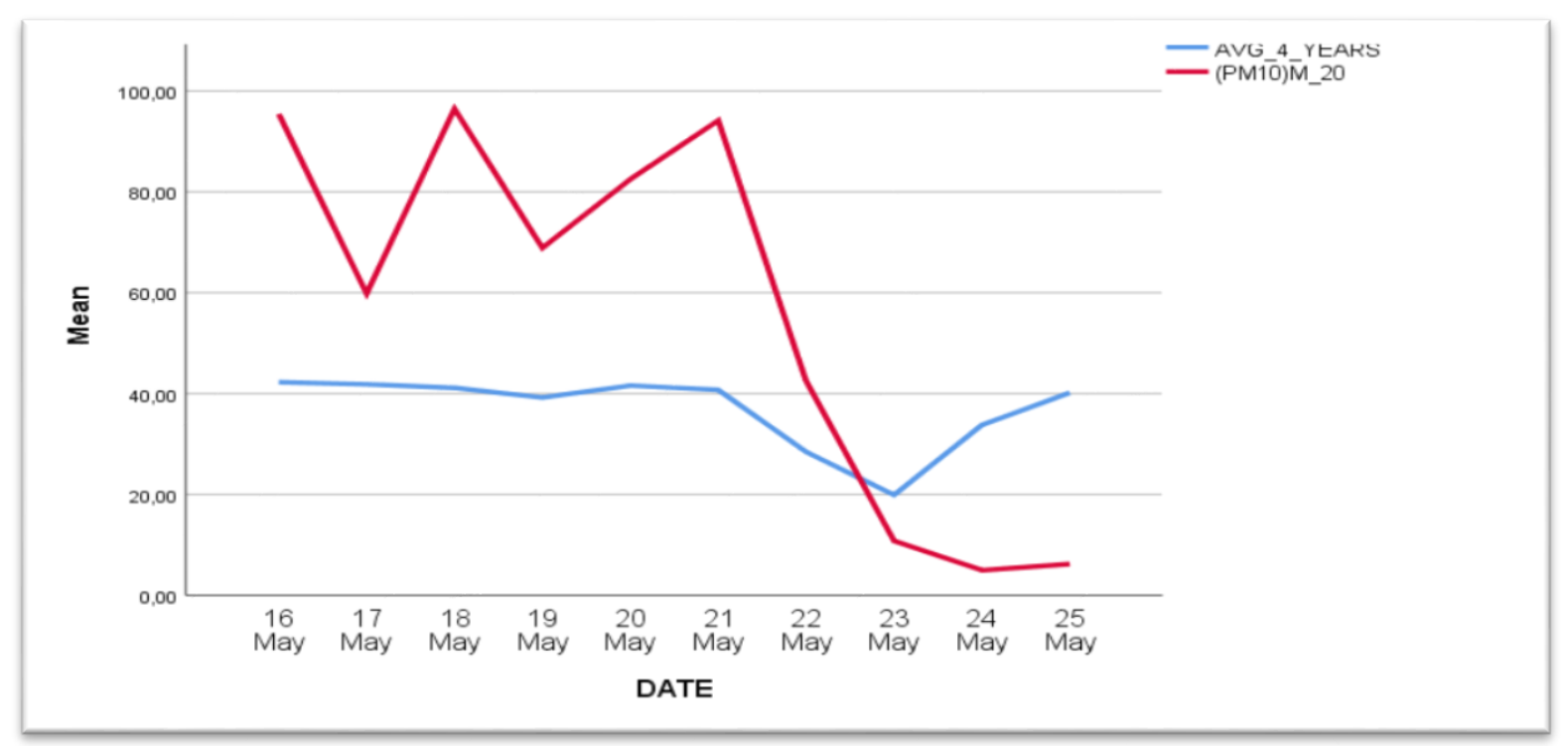

Figure 8:

Daily mean concentration $\left(\mu \mathrm{g} / \mathrm{m}^{3}\right)$ comparison of 2020 measurement of PM 10 and 4 years' average $(2015,2016,2017,2018)$

\section{CONCLUSION}

Dust storms are natural processes affecting PM pollution levels for the short term. Several health issues have been related to the short-term high PM pollution levels. Therefore, it is important to monitor PM levels during dust storm events. In this investigation, PM pollution originating from dust storms was measured 10 days period and the measurement results were compared statistically with the data taken from the closest air quality monitoring station. As a result of statistical analysis, it has been investigated that there is a significant relationship between some meteorological parameters and PM measurements. Air temperature and relative humidity 
are the major factors affecting PM pollution levels. Besides, change in $\mathrm{PM}_{2.5}$ and $\mathrm{PM}_{10}$ concentrations were explained by meteorological parameters and other pollution concentrations as $57.3 \%$ and $55.9 \%$, respectively. PCA analysis showed that 4 principal components were determined for the data set. $\mathrm{PM}_{2.5}, \mathrm{PM}^{10}$, air temperature, and relative humidity were clustered in the same component. The statistical analysis supports that PM concentrations are mainly affected by relative humidity and air temperature. Air temperature is the major contributing factor affecting PM levels positively during dust storms oppositely relative humidity has a negative contribution on PM levels. Similar results were found by the PCA study conducted for three different regions such as urban, suburban, and rural areas. PCA results of the rural area indicate that the major contributing factors to PM10 pollution were found as the air temperature with .754 positive effect and relative humidity with -.774 negative effect (Abdullah et al., 2018).

PM levels measured in this study showed that the limit values determined by EU legislation and WHO were exceeded during the dust storm period. Sensitive people who may be affected by high levels of PM pollution should be careful these days. Moreover, this study about monitoring PM during dust storm events is helpful to understand fluctuations in annual measurement and the effects of meteorological factors on particulate matter. It may be also possible to assume the potential PM levels during dust storms concerning meteorological predictions. Future studies may be conducted to produce prediction models for the dust storm cases following the results of this study.

\section{CONFLICT OF INTEREST}

The author (s) acknowledge that there is no known conflict of interest or common interest with any institution / organization or person.

\section{AUTHOR CONTRIBUTION}

Fatma Kunt contributed the writing and control of full paper, format editing and references. Zeynep Cansu Ayturan contributed to the statistical analysis and writing of all sections. Şükrü Dursun contributed to the conclusion and introduction sections.

\section{REFERENCES}

1. Abdullah, S., Ismail., M., Ahmed, A.N. (2018) Identification of Air Pollution Potential Sources Through Principal Component Analysis (PCA), International Journal of Civil Engineering and Technology (IJCIET), 9(7), 1435-1442.

2. Anonymous-1, (2020) https://tr.m.wikipedia.org/wiki/Dosya:Konya_in_Turkey.svg, Accessed Date: 25.07.2020.

3. Anonymous-2, (2020) https://gadm.org/maps/TUR/konya/selcuklu.html, Accessed Date: 25.07.2020.

4. Anonymous-3, (2020) https://libguides.library.kent.edu/SPSS/PearsonCorr, Accessed Date: 18.12.2020, Subject: SPSS Tutorials: Pearson Correlation.

5. Anonymous-4 (2020) https://www.statisticshowto.com/varimax-rotationdefinition/\#: :text=Varimax\%20rotation\%20(also\%20called\%20Kaiser,factor\%20loadings \%20for\%20the\%20rest Accessed Date: 08.01.2021, Subject: Varimax Rotation: Definition.

6. Azid, A., Juahir, H., Toriman, M.E., Kamarudin, M.K.A., Saudi, A.S.M., Hasnam, C.N.C., Aziz, N.A.A., Azaman, F., Latif, M.T., Zainuddin, S.F.M., Osman, M.R., Yamin, M. (2014) Prediction of the Level of Air Pollution Using Principal Component Analysis and Artificial 
Neural Network Techniques: a Case Study in Malaysia, Water Air Soil Pollut, 225,2063. DOI 10.1007/s11270-014-2063-1

7. Boubel, W.R., Fox, D.L., Turner, D.B., Stern, A.C. (1994) Fundamentals of Air Pollution. Third Edition. Elsevier USA, 3-153.

8. Brunekreef, B., Forsberg, B. (2005) Epidemiological evidence of effects of coarse airborne particles on health, Eur Respiratory J, 26,309-18.

9. Çelik, M.B., Kadı, İ. (2007) The Relation Between Meteorological Factors and Pollutants Concentrations in Karabük City, G.U. Journal of Science, 20(4): 87-95.

10. EPA, (2020) Pollution. https://www.epa.gov/pm-pollution, Accessed Date: 10.01.2021, Subject: Particulate Matter (PM).

11. EU, (2020) Air Quality Standards. https://ec.europa.eu/environment/air/quality/standards.htm, Accessed Date: 25.01.2021.

12. Fong, S.Y. Abdullah, Ismail, S.M. (2018) Forecasting of Particulate Matter (PM10) Concentration Based on Gaseous Pollutants and Meteorological Factors for Different Monsoons of Urban Coastal Area in Terengganu, Journal of Sustainability Science and Management, Special Issue Number 5, 3-17.

13. Google

Maps,

https://www.google.com/maps/place/Sel\%C3\%A7uklu\%2FKonya/@38.0158124,32.49395

$58,13.25 \mathrm{z} / \mathrm{data}=! 4 \mathrm{~m} 5 ! 3 \mathrm{~m} 4 ! 1 \mathrm{~s} 0 \times 14 \mathrm{~d} 0 \mathrm{edf} 71 \mathrm{~b} 511581: 0 \times 35 \mathrm{c} 05809 \mathrm{f} 6 \mathrm{f} 0 \mathrm{a} 52 \mathrm{~d} ! 8 \mathrm{~m} 2 ! 3 \mathrm{~d} 38.01603$ $83 ! 4 \mathrm{~d} 32.4920088$ ?hl=tr, Accessed Date: 25 July 2020.

14. Goudarzi, G., Mohammadi, M., Angali, K.A., Mohammadi, B., Soleimani, Z., Babaei, A., Neisi, A., Geravandi, S. (2013) Estimation of number of cardiovascular death, myocardial infarction and chronic obstructive pulmonary disease (COPD) from NO2 exposure using air Q model in Ahvaz City during 2009, Iran J Health Environ, 6, 91-102.

15. Graff, D.W., Cascio, W.E., Rappold, A., Zhou, H., Huang, Y-C.T, Devlin, R.B. (2009) Exposure to concentrated coarse air pollution particles causes mild cardiopulmonary effects in healthy young adults, Environmental Health Perspectives, 117, 1089-1094.

16. Hashim, N.I.M., Noor, N.M., Annas, S. (2018) Influence of meteorological factors on variations of Particulate Matter (PM10) concentration during haze episodes in Malaysia, 4th Electronic and Green Materials International Conference 2018, AIP Conf. Proc., 2045, 020103-1-020103-10; https://doi.org/10.1063/1.5080916.

17. Host, S., Larrieu, S., Pascal, L., Blanchard, M., Declercq, C., Fabre, P., Jusot. J-F., Chardon, B., Le Tertre, A., Wagner, V., Prouvost, H., Lefranc, A. (2008) Short-term associations between fine and coarse particles and hospital admissions for cardiorespiratory diseases in six French cities, Occupational and Environmental Medicine, 5, 544-551.

18. IBM Knowledge Center,

https://www.ibm.com/support/knowledgecenter/SSLVMB_26.0.0/statistics_casestudies_pro ject_ddita/spss/tutoria ls/fac_telco_kmo_01.html, Accessed Date: 05.01.2021, Subject: KMO and Bartlett's Test.

19. Jaafari, J., Naddafi, K., Yunesian, M., Nabizadeh, R., Hassanvand, M.S., Ghozikali, M.G., Nazmara, S., Shamsollahi, H.R., Yaghmaeian, K. (2018) Study of PM10, PM2.5, and PM1 levels in during dust storms and local air pollution events in urban and rural sites in Tehran, Human and Ecological Risk Assessment: An International Journal, 24(2), 482-493. DOI: 10.1080/10807039.2017.1389608 
20. Karakaş, B. (2015) Assessment of Particulate Matter (PM10, PM2.5 and PM1) Concentrations in Indoor and Outdoor Environments., Master of Science Thesis, Hacettepe University, Ankara Turkey.

21. Khan, Md.F., Latif, M.T., Juneng, L. Amil, N. Nadzir, M.S.M., Hoque, .M.S. (2015) Physicochemical factors and sources of particulate matter at residential urban environment in Kuala Lumpur, Journal of the Air \& Waste Management Association,65:8, 958-969, DOI: $\underline{10.1080 / 10962247.2015 .1042094 .}$

22. Linares, C., Tobías, A., Díaz, J. (2010) Is there new scientific evidence to justify reconsideration of the current WHO guidelines for particulate matter during dust intrusions? Sci Total Environ, 408, 2283-4.

23. Malig, B.J., Ostro, B.D. (2009) Coarse particles and mortality: evidence from a multi-city study in California. Occup Environ Med, 66,832-9.

24. Miller, S.D., Kuciauskas, A.P., Liu, M., Ji, Q., Reid, J., Breed, D., Walker, A., Mandoos, A. (2008) Haboob dust storms of the southern Arabian Peninsula, Journal of Geophysical Research-Atmospheres, 113,1-26. 10.1029/2007JD008550.

25. Morand, C.P., Maesano, I.A. (2004) Air pollution: from sources of emissions to health effects. Breathe, 1(2), 109-119.

26. NASA, (2020) https://worldview.earthdata.nasa.gov/, Accessed Date: 15 June 2020.

27. Qiu, H., Yu, I.T-S., Tian, L., Wang, X., Tse, L.A., Tam, W., Wong, T.W. (2012) Effects of coarse particulate matter on emergency hospital admissions for respiratory diseases: a timeseries analysis in Hong Kong, Environ Health Perspect., 120, 572-6.

28. Rahman, S.R.A., Ismail, S.N.S., Raml, M.F., Latif, M.T., Abidin, E.Z., Praveena, S.M. (2015) The Assessment of Ambient Air Pollution Trend in Klang Valley, Malaysia, World Environment, 5(1): 1-11, DOI: 10.5923/j.env.20150501.01.

29. Rathner, B. (2009) The correlation coefficient: Its values range between $+1 /-1$, or do they? Journal of Targeting, Measurement and Analysis for Marketing, 17,139-142.

30. Sritong-aon, C., Thomya, J., Kertpromphan, C., Phosri, A. (2021) Estimated effects of meteorological factors and fire hotspots on ambient particulate matter in the northern region of Thailand. Air Qual Atmos Health, https://doi.org/10.1007/s11869-021-01059-x.

31. Song, Z., Wang, J., Wang, S. (2007) Quantitative classification of northeast Asian dust events, J Geophys Res: Atmos, 112, 1-8.

32. Vesilind, P.A., Morgan, S.M., Heine, L.G. (2010) Introduction to Environmental Engineering, Cengage Leraning, Stamford-USA, 415-420.

33. Wang, S., Wang, J., Zhou, Z., Shang, K. (2005) Regional characteristics of three kinds of dust storm events in China, Atmos. Environ., 39, 509-520.

34. WHO, (2018) https://www.who.int/news-room/fact-sheets/detail/ambient-(outdoor)-airquality-and-health, Accessed Date: 1501 2021, Subject: Ambient (outdoor) air pollution.

35. Zu'ska, Z., Kopci 'nska, J., Dacewicz, E., Skowera, B., Wojkowski, J., Ziernicka-Wojtaszek, A. (2019) Application of the Principal Component Analysis (PCA) Method to Assess the Impact of Meteorological Elements on Concentrations of Particulate Matter (PM10): A Case Study of the Mountain Valley (the S acz Basin, Poland), Sustainability, 11, 6740, doi:10.3390/su1 1236740 